DOI: https://doi.org/10.34069/AI/2021.48.12.19

How to Cite:

Jumayev, F. (2021). The role of the developed and developing economies in the Central Asian countries' economic growth. Amazonia Investiga, 10(48), 181-188. https://doi.org/10.34069/AI/2021.48.12.19

\title{
The role of the developed and developing economies in the Central Asian countries' economic growth
}

\section{Роль развитых и развивающихся экономик в экономическом росте стран Центральной Азии}

Received: December 2, 2021

\begin{abstract}
The current state of economic development of the countries of Central Asia is controversive. Their GDP grows faster than the global GDP, but their economies from the other hand are extremely ineffective in distribution of wealth, the use of gained resources. In order to overcome this, multiple mechanisms are created, namely the development banks and institutions, BRI, EAEU etc. These institutions represent the interests of the major regional players. The article concentrates on the interests of Asian countries and Russia, giving a glance on the mechanisms these countries use and their real power in the region. The author conducted statistical analysis, used dilogical approach to the gains and losses of the economies of Central Asia in the context of their cooperation with major players - PRC, Russia, Japan and others. The risks of such cooperation were revealed too, firstly, the risks for economic growth, but including the risks of social character. The results of the study demonstrate that the current situation is far from positive, as every positive influence is controversed by negative. In this regard, the major finding $\mathrm{s}$ include this controversy, the recommendations for easing the issues of economic cooperation, the practical proof of the tightening grip of PRC on the region and the weakening influence of Russia in Central Asia.
\end{abstract}

Keywords: Central Asia, PRC, Russia, economic growth, risks, institutions, strategy.
Accepted: December 28, 2021

Written by:

Farrukh Jumayev ${ }^{78}$

https://orcid.org/0000-0002-2604-6811

\begin{abstract}
Аннотация
Текущее состояние экономического развития стран Центральной Азии неоднозначно. Их ВВП растет быстрее, чем мировой ВВП, но с другой стороны их экономика крайне неэффективна в распределение богатства и использование полученных ресурсов. Чтобы преодолеть это, создается множество механизмов, а именно банки и институты развития, ОПОП, ЕАЭС и т. д. Эти институты представляют интересы основных региональных игроков. В статье рассматриваются интересы азиатских стран и России, рассматриваются механизмы, которые эти страны используют, и их реальное влияние в регионе. Автор провел статистический анализ, использовал дилогический подход к прибылям и убыткам экономик Центральной Азии в контексте их сотрудничества с крупными игроками - КНР, Россией, Японией и другими странами. Выявлены, в первую очередь, риски экономического роста, также риски социального характера. Результаты исследования показывают, что текущая ситуация далека от положительной, так как любое положительное влияние противоречит отрицательному. В этом отношении основными выводами являются это противоречие, рекомендации по смягчению вопросов экономического сотрудничества, практическое доказательство ужесточения власти КНР в регионе и ослабления влияния России в Центральной Азии.
\end{abstract}

Ключевые слова: Центральная Азия, КНР, Россия, экономический рост, риски, институты, стратегия.

\footnotetext{
${ }^{78} \mathrm{PhD}$, Economics Department, Kyung Hee University, Seoul, Republic of Korea.
} 


\section{Introduction}

The The Central Asian region encompasses several developing economies, namely Mongolia, Kazakhstan, Uzbekistan, Kyrgyz Republic, Tajikistan and Turkmenistan. Obviously, these countries are uneven in their economic development and the prospects of social and economic character. These countries are experiencing several significant issues, and there are multiple institutions and countries, aiming to help them (Egorycheva, 2019; Kazantsev et al. 2021; Rakhimov, 2014; Juraev, 2014).

The article aims at revealing the impact of the cooperation with these institutions and countries for the economies of Central Asia. The scope of the article limits the variety of these institutions to one group - Asian countries and institutions. This choice is substantialized by the actuality of the estimation of the Asian countries' influence on Central Asia. The first are one of the most dynamically developing economies in the world, the center of economic and financial power moves to Asia (Bajpal, 2012; Shah, 2019). At the same time, there are several risks for the economies of Central Asia in this process, the most important of which is the high dependency on the incoming development support.

The major tasks, solved in the article are the following: the major economic and political actors in the region are revealed, the influence of these actors is grounded by the correlation analysis, the risks of cooperation with Asian economies proved and the possible options for decreasing these risks proposed.

The key findings of the article encompass the proposed approach to the correlation analysis as the instrument of the influence comparison in the region with two major superpowers, the proposed solutions for the problems of economic development of the Central Asian economies, the dilogical approach to the factors and influence of third parties, including states on the development of Central Asian economies.

\section{Methodology}

Here The assessment of the influence and risks of cooperation with the Asian economies and regional superpowers for the Central Asian economies is conducted from the point of view of analysis of the major geoeconomics instruments these powers use - the international institutions and the MNCs. The other method used is the econometric and statistical analysis.
In order to assess the influence of Russia and China on the economies of Central Asia, we propose the correlation analysis in the following interpretation. The first step is to assess the correlation of GDP values in between 1990 and 2020. The next step is to assess the correlation in every decade, which will allow to figure out the short-term effects. The long-term effects refer to geopolitical, geoeconomics and cultural influence, as it doesn't change over time too fast, while the short-term correlation demonstrates the financial and economic influence in general. The higher the value, the higher the influence.

In order to figure out the influence and risks of cooperation connection the dilogical analysis was conducted, where based on the revealed risks and benefits the same economic happening was viewed as positive and negative. This analysis allowed to put forward several solutions for easing the issues of economic growth of Central Asian economies.

\section{Results and Discussion}

This First and foremost, lets figure out the major influencing parties in the Central Asian region. The obvious result of this analysis is the fact, that all the major regional players are interested in the influence in Central Asia as the region that: interconnects the Asian and European countries and Asia and the Persian Gulf, just as it has the easiest and the shortest way from the Northern parts of Eurasia to the Southern, India, for instance (Contessi, 2020; Vinokurov, et al. 2016; Emerson, \& Vinokurov, 2009) has a significant growth of the population and workforce, along with the high unemployment and cheap labor, providing competitive advantages for the companies; is rich in natural resources, metals, coal, potentially has shale oil (Raimondi, 2019; Pomfret, 2010), but has no national resources for their extraction. The named reasons lead to the possibility to put into life economic development strategies, based on the competitive advantages of the region for non-regional economies, to put it simple - to exploit the regional resources.

In this regard, the major influential players are: Russia - it inherits the economic, cultural and political bonds of the USSR in Central Asia, China - it promises high economic results for the countries in return for the participation of the Chinese companies in their economies (Pradhan, 2017; Özcan, 2021), Europe in general, as it had a real liberal alternative for the Central Asian 


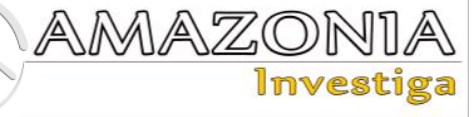

economies before the migration crisis and the COVID-19 crisis.

The strongest points and influential ideas of the countries are listed and discussed hereinafter. Russia has the potential to provide economic help in moderate volumes, but it's one of the major foreign labor markets for the population of some of the countries in Central Asia. Mongolia and Kazakhstan don't fall into this scheme, but Kazakhstan is a member of EAEU - the Russian geopolitical alternative for the European EU and the Chinese Belt and Road Initiative, while Mongolia has no other neighbors than Russia and China. It follows the strategy of balancing between the two superpowers, seeking from Russia support and balance for the Chinese expansion - both economic and political (Rumer, 2006; Wilson, 2021).

China from the other hand, has significant and strong economic mechanisms, such as the BRI, which provides support for the infrastructure development in the countries, which join it. The other positive side of cooperation with China is the strong participation of the Chinese multinational companies in the economies of the
PRC partner countries. It brings the investments and the working places instead this cooperation provokes the so-called sinoization, the strategy China uses for the economic binding of its partners (Carnegie, 2020; Mariani, 2013; Kashin, Korolev, 2018).

Europe and EU have little or no power in the region today, the most influential mechanism CAREC gives little to its members, it attracted only $\$ 39,34$ billions of investments (Carec, 2020), which can't be compared with the impact of the BRI (at least $\$ 950$ billions during the existence of the Initiative) (The Green Finance \& Development Center, 2021). Still the choice of the political vision sometimes leads Central Asian economies to the liberal Europe, rather than to the centralized China and Asian economies.

In this regard, the major task is to assess the state of competition for the Central Asian economies between Russia and China. This is done according to the proposed methodology with the correlation analysis. The results are presented in table 1 .

Table 1.

The results of correlation analysis (developed by author, based on (Worldbank, 2020)

\begin{tabular}{lllllllll}
\hline & $1990-2020$ & \multicolumn{2}{l}{$1990-1999$} & \multicolumn{2}{l}{$2000-2009$} & \multicolumn{2}{l}{$2010-2020$} \\
\cline { 2 - 9 } & China & Russia & China & Russia & China & Russia & China & Russia \\
Kazakhstan & 0,894 & 0,979 & $-0,790$ & 0,859 & 0,967 & 0,992 & $-0,137$ & 0,876 \\
Kyrgyz & 0,969 & 0,907 & $-0,846$ & 0,900 & 0,985 & 0,969 & 0,888 & 0,019 \\
Republic & & 0,903 & $-0,488$ & 0,616 & 0,960 & 0,994 & 0,786 & 0,183 \\
Mongolia & 0,971 & 0,969 & 0,260 \\
Tajikistan & 0,947 & 0,930 & $-0,740$ & 0,556 & 0,991 & 0,965 & 0,585 & 0,25 \\
Turkmenista & 0,983 & 0,893 & $-0,033$ & $-0,036$ & 0,996 & 0,934 & 0,863 & 0,030 \\
n & 0,902 & 0,850 & 0,810 & $-0,813$ & 0,972 & 0,873 & 0,039 & $-0,071$ \\
\hline
\end{tabular}

Based on the results of table 1, we can make several important implications:

1) Russia has a strong influence in the region, but it's based on culture, geopolitics and geoeconomics

2) China has gained economic and financial influence and due to the global crises, this influence is dominant, as the countries want to get the most from the current conditions, losing strategic vision

3) Kazakhstan is the only country with the remaining influence of Russia, proving that EAEU is an effective policy
4) Turkmenistan, Mongolia and Kyrgyz Republic follow the Chinese economy in their development, demonstrating the efficiency and scope of the Chinese Belt and Road Initiative.

The Chinese BRI has become the leading trend in the infrastructural and economic development of Central Asia. The economies of Central Asia have been receiving significant economic bonuses from cooperation with the Chinese MNCs, the major characteristics of this cooperation are reflected in table 2 . 
Table 2.

The Chinese MNCs' projects in Central Asia (developed by author, based on (AEI, 2021)

\begin{tabular}{|c|c|c|c|c|}
\hline Country & $\begin{array}{l}\text { Number } \\
\text { of } \\
\text { projects }\end{array}$ & $\begin{array}{l}\text { Volume of } \\
\text { investments, } \\
\$ \text { millions }\end{array}$ & Chinese compnies & Major sectors \\
\hline $\begin{array}{l}\text { Kazakhsta } \\
\text { n }\end{array}$ & 38 & 32630 & $\begin{array}{l}\text { CNPC, CITIC, Sinopec, Geo-Jade Petroleum, } \\
\text { China Railway Engineering, China Railway } \\
\text { Construction }\end{array}$ & $\begin{array}{l}\text { Energy, } \\
\text { metals, } \\
\text { transport }\end{array}$ \\
\hline $\begin{array}{l}\text { Kyrgyz } \\
\text { Republic }\end{array}$ & 9 & 4730 & $\begin{array}{l}\text { Shaanxi Coal and Chemical, Beijing Urban } \\
\text { Construction, CNPC }\end{array}$ & $\begin{array}{l}\text { Energy, } \\
\text { transport }\end{array}$ \\
\hline Mongolia & 14 & 6280 & $\begin{array}{l}\text { Power Construction Corp, Tebian Electric } \\
\text { Apparatus, CIC, Shenhua, China Energy } \\
\text { Engineering }\end{array}$ & Energy \\
\hline Tajikistan & 5 & 1610 & $\begin{array}{l}\text { China Communications Construction, Tebian } \\
\text { Electric Apparatus, China National Building } \\
\text { Material }\end{array}$ & $\begin{array}{l}\text { Transport, } \\
\text { Energy, Real } \\
\text { estate }\end{array}$ \\
\hline $\begin{array}{l}\text { Turkmeni } \\
\text { stan }\end{array}$ & 4 & 6800 & CNPC & Energy \\
\hline $\begin{array}{l}\text { Uzbekista } \\
\mathrm{n}\end{array}$ & 14 & 5440 & $\begin{array}{l}\text { CNPC, China Poly, Jiangsu Hengyan, Harbin } \\
\text { Electric }\end{array}$ & $\begin{array}{l}\text { Energy, Real } \\
\text { estate, } \\
\text { Agriculture }\end{array}$ \\
\hline
\end{tabular}

Table 2 reflects the high interest of China in Kazakhstan, as the major Russian partner in the region, although the projects in other countries have comparable volume. This is another proof of the influence of financial and economic strategy of China on geopolitics, or at least, the endeavor to provide that influence.

The other Asian economies also participate in the regional development, but on a smaller scale. Japan, for instance, uses its geoeconomics development institution - The Asian Development Bank (Lim, \& Vreeland, 2013) Figure 1 reflects the major countries of interest for the ADB, hence for Japan too - these are Uzbekistan and Kazakhstan, while the latter is a quite clear sphere of interest due to its oil and gas resources and mineral resources, the interest for Uzbekistan from the first glance isn't that clear, but when referring to trade relations, Japan is among 10 of the biggest trade partners of Uzbekistan, the country imports machinery, automobiles, technical devices, the growing export of Uzbekistan to Japan consists of metals, textile and food products. From this point of view, the Japanese interests in Uzbekistan are clear, especially when thinking of the flying geese strategy (Korhonen, 1994).

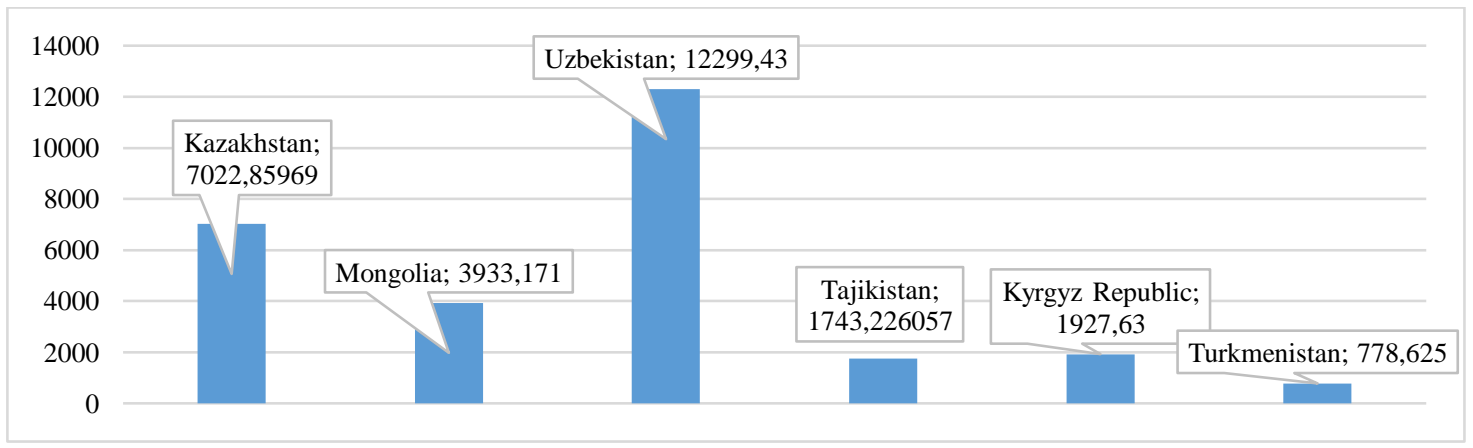

Figure 1. Volume of investments from ADB (\$ million) (developed by author, based on (ADB, 2020).

Korea also has interests in Central Asia, which are of commercial character, it competes with China for the regional markets (Fumagalli, 2012; Hwang, 2021). The interests of PRC, India and Russia have another dimension - the security dimension. The countries of the region prove to be a source of drug trafficking and terrorism transportation (Mihr, 2020), which doesn't suite the interests of none of the regional players. The cooperation inside the Shanghai Cooperation Organization adds to the security of the region, but also builds the tight intergovernmental relations and helps form the basis for further economic cooperation. 


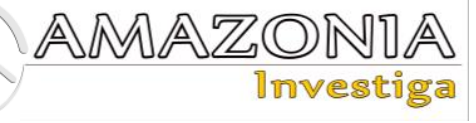

From one point of view, the risks of such tight and profitable cooperation can be neglected because of the incredible economic effect. Still, the other position states, that the significance of risks is underestimated (as it was shown in (Rumer, 2006; Wilson, 2021). Let's figure out the major risks for the economies of Central Asia.

First and foremost, the investments from any player are given in exchange for something - in case of China it's the Chinese participation in the economy, in case of Russia - it's loyalty to the Russian geopolitical strategy, Japan, just as EU states that its institutions invest on conditions of democratization of society etc. All these moments lead to the high limitations for the national development of the economies of Central Asia.

Secondly, the major spheres of interest of the investing parties encompass only a few, namely, energy, real estate, metals or natural resources and transport. Transport is the only of use for the development of the local economies, as it allows to participate in the global logistics (Karymshakov, \& Sulaimanova, 2021). The other industries aim at the exploitation of the regional natural and human resources, mainly leaving the economy on the same development stage or dependent on exports of raw materials. This is a significant structural problem, caused by such investment and cooperation strategy.

Thirdly, the MNCs of the named countries are tightly interconnected with the proliferation of the resident states' interests. It's quite true for the Russian energy sector, for the Chinese strategy of "soft power", for the Japanese "flying geese". In this regard the active participation if these MNCs in the local economies leads to their dependency not only on governments of the investing countries, but on their MNCs too.

The fourth risk is connected with the labor market. It's true, that the labor quality in Central Asia is low (Mirkasimov, Ahunov, 2017; Batsaikhan, Dabrowski, 2017), bad education, bad loving and working standards, little or no work culture enhances the problem. The foreign companies use their own top managers and management in general, when working in Central Asia (Dietz, et al. 2008; Meng, et al. 2019) leaving the rest of their employees with bad salaries and little professional education. It commits to the stagnation of the local economies, but also it can lead to the social unrest because of inequality.

The fifth risk has been mentioned earlier - it's the security issue. The majority of the Central Asian countries face crime, drugs trafficking and terrorism issues, which are bolstered by the social unrest and poverty. None of the measures of economic character taken by the institutions and investor countries have the power to solve these issues on their own. SCO doesn't have such power too. Hence these risks are a constant, that doesn't change for a long time.

When the risks from Central Asia and influence of the most influential players on the economy of the countries of the region is figured, let's finalize the impact of the developing and developed economies on the economic growth of the region. Let's refer to table 3.

Table 3.

The influence of the Asian economies on the economic growth of Central Asia (created by author)

\begin{tabular}{|c|c|}
\hline Positive for economic growth & Negative for economic growth \\
\hline $\begin{array}{l}\text { Investments stimulate economic } \\
\text { growth }\end{array}$ & Investments stimulate economic dependency on new investments \\
\hline $\begin{array}{l}\text { Political and economic influence } \\
\text { allow to promote successful } \\
\text { governance and economic models }\end{array}$ & $\begin{array}{l}\text { Political and economic influence allows to pull the Central Asian } \\
\text { economies in a geopolitical struggle of superpowers }\end{array}$ \\
\hline $\begin{array}{l}\text { MNCs provide investments and } \\
\text { economic support }\end{array}$ & MNCs exploit the resources of the countries of the region \\
\hline $\begin{array}{l}\text { MNCs introduce high industrial } \\
\text { standards }\end{array}$ & The introduced standards don't fully refer to the local workers \\
\hline $\begin{array}{l}\text { Economic development is followed } \\
\text { by the better living standards }\end{array}$ & The widening gap of living standards leads to social unrest \\
\hline $\begin{array}{l}\text { SCO and other international } \\
\text { institutions promote security in } \\
\text { Central Asia }\end{array}$ & $\begin{array}{l}\text { SCO and other international organizations just as the investor } \\
\text { countries aren't capable to provide efficient protection from } \\
\text { terrorism and drug trafficking, although having a significant impact } \\
\text { on better situation }\end{array}$ \\
\hline
\end{tabular}


Table 3 proves the controversial effect of the economic cooperation of Central Asian countries with the major regional powers. Some of the negative consequences can be smoothened by the coordinated policies of the international institutions and regional powers.

\section{Discussion}

The negative effects for economic growth are difficult to overcome, but they can be less devastating. In order to achieve that, the following steps for the better future of the countries in the region are suggested.

In order to overcome the growing dependency on the investments, it's useful to introduce a filter strategy. It includes the creation of the legal limitation framework for the investments in mining, real estate and financial system, while providing special tax regimes for investments in transport, infrastructure, social services, local industries' development. A similar strategy was used by China to protect the vulnerable industries or the ones of the importance for national security (Latham \& Watkins Data Privacy \& Security Practice, 2021). It will inevitably lead to the competition for the development of the limited for investments industries and higher returns, while boost investments in socially important industries with loyal tax regime as an instrument for the diversification of investments.

The game of superpowers in Central Asia is inevitable and none of the regional countries will avoid it. The most efficient strategy is to balance between these powers, just as Mongolia has been doing ever since the fall of the USSR (Campi, 2020; Her, 1997). At the same time, this strategy is a game on the razorblade, which can turn to be dangerous for the economy of a country. The only solution is to participate in all interactions' formats in the region - both institutional and bilateral. SCO, EAEU, BRI, ADB, AIIB and other institutions prove to have a binding power and prevent the worst consequences. This strategy is a Markovitz portfolio of a kind - if one institution refuses credit for political reason, the other will approve it on better conditions for the same political reason: big politics can be profitable for small economies.

As it follows from the history of MNCs' actions in the small economies, the minority of the latter managed to gain only positive effects. In order to limit the powers of the MNCs it's necessary to introduce legal framework, limiting their power. It's recommended to concentrate on: the quotas for national workers, the quotas for the national financial participation, the duty to use the national financial system for the conduct of payments, the duty to provide ESG-standards reports, the use of international legal mechanisms for dispute settlement.

The issue with the local workforce is a significant issue with no clear answer. The recommendations on local workers quotas help solve the issue only partially, while the major discrimination issue can be eased by ESG reports. Still the overall problem will remain the employees of the MNCs and the ones, who migrate in search of jobs abroad, to Russia for instance, live better and earn more, than the employees of the local companies.

The social gap is always a significant issue in the fast-developing economies. One of the possible solutions is tighter control over corruption, crimes in financial sphere etc., but these measures work in countries with high centralization and law obedience. The Central Asian economies have problems with correlation of the legal base and real practice. The expansion of the CAREC-based mechanism for institutional development in transport can be the first step in institutional transformation, but all in all, such transformations take a long time.

Security issues in Central Asia can be solved with the expansion of the SCO mandate and the cooperation of intelligence agencies of these countries with special forces in Russia and China. The expansion of SCO mechanism should include the creation of special peace forces, special antiterrorist forces and special counterdrug forces under the control of the Organization and the mandate for their use in Central Asia on the decision of the Operational headquarter of SCO. This will contribute to the effective and rapid cease of conflict in any of the mentioned spheres of security and these forces will be backed up in case of serious issues by the joint Russian and Chinese forces. This mechanism gives Russia and PRC the duty to provide peace and stability in the region under the governance of the joint mechanism of security - SCO in order to avoid misuse of these duties and rights.

The proposed measures are a significant part of the regional economic development, but the last measure is the creation of the Joint Plan for Actions for the Economic Development of Central Asia with technical and consultative assistance of the development banks, namely EAEU, ADB and AIIB, which represent the major interest parties, but by the governments of the Central Asian countries. This Plan should 


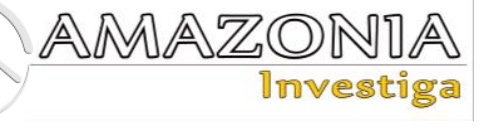

include all the mentioned above measures and the expanded recommendations, grounded by the local governments and authorities.

\section{Conclusions}

The major findings of the article include the following points:

1) Russia and China are the main influencers in the region. The latter relies on the short-run instruments, while the first on the geopolitical, geoeconomical and cultural cooperation, which pay out in long-run.

2) China is gaining significant influence in Central Asia, including the influence, gained through the BRI.

3) EU, Japan, Korea and India also have economic interests in the region, but only Japan has relevant instruments for their pursue, the others compete for the market share and have nearly no significant power in Central Asia.

4) Economic development of the region is boosted by the investments from the global institutions and investor-countries, from the participation of the MNCs and from security cooperation, but the investments lead to dependency, countries pursue their own political and economic interests and exploit the natural resources of the regional economies, MNCs serve the interests of the residency countries and cause the same issues, but also stimulate social inequality, social unrest, security cooperation eases, but doesn't solve security issues.

5) This dilogical influence on the economic growth can be transformed for better effects by limiting the possibilities for wild and speculative investments, the introduction of limits and SDG standards for MNCs, the reformulating the legal base of foreign participation in the Central Asian countries' economies, the extension of the SCO mandate, the transfer of institutes and the development of the Joint Plan for Economic Development, which will include and expand the recommendations, formulated above.

The proposed strategy ban be of practical use for the international organizations, MNCs, governments of the Central Asian countries and should be expanded and adapted for the regional and current needs.

\section{Bibliographic references}

ADB. (2020). ADB Sovereign Projects. Available at: https://data.adb.org/dataset/adb-sovereignprojects

AEI. (2021). China Global Investment Tracker. Available at: https://www.aei.org/china-globalinvestment-tracker/

Bajpal, A. (2012). The "Rise Of Asia" Thesis: strategic constraints and theoretical deficits. World Affairs: The Journal of International Issues, 16(2), 12-37. https://www.jstor.org/stable/48504921

Batsaikhan, U., \& Dabrowski, M. (2017). Central Asia - twenty-five years after the breakup of the USSR, Russian Journal of Economics, 3(3), 296-320, DOI: 10.1016/j.ruje.2017.09.005.

Campi, A. (2020). Mongolia's response to increasing U.S.-China-Russia rivalry in Asia. Asia Pacific Bulletin, No. 521. Available at: https://www.eastwestcenter.org/publications/m ongolia\%E2\%80\%99s-response-increasing-uschina-russia-rivalry-in-asia

Carec. (2020). What is CAREC? Available at: https://www.carecprogram.org/?page_id=31

Carnegie. (2020). China in Central Asia: COVID19 and Beyond. Available at: https://carnegieendowment.org/2020/09/08/chi na-in-central-asia-covid-19-and-beyond-event7413

Contessi, N.P. (2020). In the Shadow of the Belt and Road. Eurasian Corridors on the NorthSouth Axis. Available at: https://reconasia.csis.org/shadow-belt-androad/

Dietz, M.C. Orr, G., \& Xing, J. (2008). How Chinese companies can succeed abroad. McKinsey quarterly, 3, 22. Available at: https://www.researchgate.net/publication/2888 51507_How_Chinese_companies_can_succeed _abroad

Egorycheva, E.A. (2019). Central Asia as an area of China's and Russia's interests. RUDN Journal of Economics, 27(4), 732-742. DOI: 10.22363/2313-2329-2019-27-4-732-742

Emerson, M., \& Vinokurov, E. (2009). Optimisation of Central Asian and Eurasian Inter-Continental Land Transport Corridors. MPRA Paper No. 20916. Available at: https://mpra.ub.uni-muenchen.de/20916/

Fumagalli, M. (2012). South Korea's Engagement in Central Asia from the End of the Cold War to the "New Asia Initiative". The Journal of Northeast Asian History, 9(2), 69-97.

Her, E. (1997). Ehe "great game": Mongolia between Russia and china. The Mongolian Journal of International Affairs, № 4.

Hwang, B. (2021). A New Horizon in South KoreaCentral Asia Relations: The ROK Joins the "Great Game". Korea Economic Institute. Available at: 
http://keia.org/sites/default/files/publications/k ei_koreacompass_template_balbinahwang.pdf

Juraev, S. (2014). Comparing the EU and Russia engagements in Central Asia. L'Europe en Formation, 374, 77-93. https://doi.org/10.3917/eufor.374.0077

Karymshakov, K. \& Sulaimanova, B. (2021). The impact of infrastructure on trade in Central Asia. Asia Europe Journal, 19. DOI: 10.1007/s10308-021-00613-7

Kashin V., \& Korolev A. (2018). China's Foreign Aid to Central Asia States. World economy and international relations, 62(3), pp. 78-85. DOI: 10.20542/0131-2227-2018-62-3-78-85

Kazantsev, A, Medvedeva, S, \& Safranchuk, I. (2021). Between Russia and China: Central Asia in Greater Eurasia. Journal of Eurasian Studies, 12(1), 57-71. DOI: $10.1177 / 1879366521998242$

Korhonen, P. (1994). The Theory of the Flying Geese Pattern of Development and Its Interpretations. Journal of Peace Research, 31(1), 93-108.

Latham \& Watkins Data Privacy \& Security Practice (2021). China Issues New Regulations to Protect the Critical Information Infrastructure, Number 2892. Available at: https://www.lw.com/thoughtLeadership/ChinaIssues-New-Regulations-to-Protect-theCritical-Information-Infrastructure

Lim, D., \& Vreeland, J. (2013). Regional Organizations and International Politics: Japanese Influence over the Asian Development Bank and the UN Security Council. World Politics, 65(1), 34-72. doi: 10.1017/S004388711200024X

Mariani, B. (2013). China's role and interests in Central Asia. Saferworld. Available at: https://www.files.ethz.ch/isn/172938/chinasrole-and-interests-in-central-asia.pdf

Meng, S., Yan, J. \& Cao, X. (2019). Heterogeneity in top management teams and outward foreign direct investment: evidence from Chinese listed companies. Front. Bus. Res. China, 13, 16. https://doi.org/10.1186/s11782-019-0063-0

Mihr, A. (2020). Webs of corruption: trafficking and terrorism in central Asia. International Affairs, 96(1), pages 252-253, https://doi.org/10.1093/ia/iiz266

Mirkasimov, B., and Ahunov, M. (2017). Labor markets and informality: the case of Central Asia. Mpra. Available at: https://mpra.ub.unimuenchen.de/78751/1/MPRA_paper_78751.pd $\mathrm{f}$

Özcan, G.B. (2021). Chinese Business in Central Asia: How Crony Capitalism is Eroding Justice.
Foreign Policy Research Institute. Available at: https://www.fpri.org/article/2021/03/chinesebusiness-in-central-asia-how-crony-capitalismis-eroding-justice/

Pomfret, R. (2010). Exploiting Energy and Mineral Resources in Central Asia, Azerbaijan and Mongolia. Comparative Economic Studies, 53(2010-16). DOI: 10.1057/ces.2010.24

Pradhan, R. (2017). China's Rise in Central Asia: The new silk road economic belt. World Affairs: The Journal of International Issues, 21(3), 50-61. https://www.jstor.org/stable/48531352

Raimondi, P.P. (2019). Central Asia Oil and Gas Industry - The External Powers' Energy Interests in Kazakhstan, Turkmenistan and Uzbekistan. FEEM Working Paper No. 6.2019, DOI 10.2139/ssrn.3386053

Rakhimov, M. (2014). Central Asia and Japan: Bilateral and multilateral relations. Journal of Eurasian Studies, 5(1), pages 77-87. DOI: 10.1016/j.euras.2013.09.002

Rumer, E.B. (2006). China, Russia and the Balance of Power in Central Asia. Strategic Forum, 223. Available https://www.files.ethz.ch/isn/46312/SF223.pdf

Shah, J. (2019). Asian Economic Dynamics and Power Shifts. Advances in Economics and Business, 7(1), 31-38. DOI: 10.13189/aeb.2019.070104

The Green Finance \& Development Center. (2021). Chinese BRI Investment 2013-2020. Available at: $\quad$ https://greenfdc.org/wpcontent/uploads/2021/02/China-Investmentsin-the-Belt-and-Road-Initiative-2013-2020.png

Vinokurov, E., Balas, P., Emerson, M., Havlik, P., Pereboyev, V., Rovenskaya, E., Stepanova, A., Kofner, J., \& Kabat, P. (2016). Development of Transport and Infrastructure in Eurasia IIASA project "Challenges and Opportunities of Economic Integration within a Wider European and Eurasian Space". Workshop Report. International Institute for Applied Systems Analysis. Available at: http://pure.iiasa.ac.at/id/eprint/13965/1/Develo pment $\% 20$ of $\% 20$ Transport\%20and\%20Infrastr ucture\%20in\%20Eurasia.pdf

Wilson, J. 1. (2021). Russia and China in Central Asia: Deepening Tensions in the Relationship. ACTA VIA SERICA, 6(1), 55-90. DOI: 10.22679/avs.2021.6.1.003

Worldbank. (2020). GDP (current US\$). Available at: https://data.worldbank.org/indicator/NY.GDP. MKTP.CD 